\title{
MENINGKATKAN PERKEMBANGAN SOSIAL ANAK MELALUI METODE BERMAIN SECARA KOLABORATIF
}

\author{
Vera Kristiana Ariin ${ }^{1}$ \\ Edi Rohendi ${ }^{2}$ \\ Tuti Istianti ${ }^{3}$
}

\begin{abstract}
ABSTRAK
Penelitian ini dilaksanakan berdasarkan pada permasalahan yang ditemukan oleh peneliti mengenai kurang berkembangnya perkembagan sosial anak terutama pada hal kerjasama dan interaksi dengan teman di sekolah TK Sukahaji kelompok B. Subjek penelitian sebanyak 13 anak, yang terdiri dari 5 anak laki-laki dan 8 anak perempuan. Tujuan penelitian tersebut adalah (1) untuk meningkatkan perkembangan sosial anak melalui metode bermain secara kolaboratif, (2) untuk mengetahui hasil perkembangan sosial anak melalui metode bermain secara kolaboratif. Kegiatan yang dilaksanakan yaitu dengan bermain diantaranya permainan memasukan pensil ke botol, pindah sarung, galah asin, puzzle, bakiak dan lain-lain yang dilakukan secara berkelompok yang didalamnya terdapat interaksi antar anak dalam kelompok. Kegiatan bermain merupakan suatu kegiatan yang sangat bermanfaat bagi anak dalam mengembangkan berbagai keterampilan anak. Bermain secara kolaboratif memberikan kesempatan kepada anak untuk bekerjasama dan berinteraksi dalam kelompok. Metode penelitian ini menggunakan Penelitian Tindakan Kelas (PTK) dengan model Elliot, yakni terdiri dari 3 siklus dan 9 tindakan. Teknik pengumpulan data menggunakan beberapa teknik yakni observasi guru, observasi anak, wawancara anak, penilaian proses, catatan lapangan dan dokumentasi. Data yang diperoleh kemudian dideskripsikan pada hasil penelitian serta direfleksikan untuk merencanakan pembelajaran selanjutnya. Hasil penelitian ini menunjukan bahwa (l)meningkatkannya perkembangan sosial anak melalui metode bermain secara kolaboratif, (2) hasil perkembangan sosial anak meningkat setelah diterapkannya metode bermain secara kolaboratif, rata-rata kelas pada siklus 1 yaitu 1,78 meningkat pada siklus 2 rata-rata kelas menjadi 2,09 dan rata-rata kelas siklus 3 mengalami peningkatan menjadi 2,69. Dengan demikian dapat diambil kesimpulan bahwa menggunakan metode bermain secara kolaboratif dapat meningkatkan perkembangan sosial anak. Diharapkan semua pihak sadar pentingnya pencapaian perkembangan sosial pada anak, karena dengan optimalnya perkembangan sosial pada anak, maka aspek perkembangan lainnya pun berkembang secara optimal.
\end{abstract}

Kata Kunci: Perkembangan Sosial Anak, Bermain, Kolaboratif

\footnotetext{
${ }^{1}$ veraariin@gmo/7.com

${ }^{2}$ Dosen Kampus UPI Cibiru

${ }^{3}$ Dosen Kampus UPI Cibiru
} 


\section{A. PENDAHULUAN}

Pendidikan anak usia dini adalah suatu wahana pendidikan dan pembinaan yang ditujukan kepada anak usia 0-6 tahun sebagai upaya rangsangan dan stimulus untuk membantu anak dalam mengoptimalkan seluruh potensinya sebagai bekal hidupnya dan untuk memiliki kesiapan dalam memasuki pendidikan lebih lanjut. Pendidikan yang diberikan pada anak usia dini akan mempengaruhi anak pada masa selanjutnya. Pendidikan yang haras diberikan pada anak yaitu suatu pembelajaran yang dapat mengembangkan seluruh aspek perkembangan yaitu aspek perkembangan kognitif, bahasa, sosio-emosional, fisik motorik, moral dan agama. Keenam aspek tersebut hendaknya dapat terfasilitasi dengan baik guna membentuk karakter yang utuh dan dapat menyesuaikan diri pada kehidupannya kelak hal tersebut sesuai dengan Menteri Pendidikan dan Kebudayaan no 137 dan 146 tahun 2014 yang memuat beberapa aspek perkembangan anak usia dini, yaitu aspek moral dan agama, kognitif, fisik motorik, bahasa, sosial emosional, serta seni. Salah satu perkembangan yang penting yaitu perkembangan sosial anak dimana manusia hidup di dalam lingkungan sosial dan tak bisa hidup sendiri sejak kanak-kanak sampai dewasa. Menurut Yusuf (2006, him, 122) mengatakan bahwa "Perkembangan sosial merapakan pencapaian kematangan dalam hubungan sosial" dapat diartikan bahwa perkembangan sosial adalah suatu proses pencapaian menyesuaikan diri dengan apa yang menjadi adat, tradisi, moral dan normanorma kelompok. Salah satu tujuan pendidikan yaitu menciptakan individu yang utuh baik dalam kognitif, sosial dan sebagainya sebagai dasar dari kepribadian dan karakter.

Pada perkembangan sosialnya individu akan terbagi menjadi dua tipe/kelompok, yaitu kelompok individu sosial dan nonsosial, hal tersebut diperjelas oleh Herawati (2006). Kelompok individu sosial ialah individu yang mampu menyesuaikan diri atau beradaptasi, mengikuti dan memenuhi harapan dilingkungannya dan diterima sebagai anggota kelompok. Sedangkan individu nonsosial adalah individu yang tidak bisa beradaptasi atau menyesuaikan dirinya dengan harapan social maka kecenderangannya menjadi individu antisosial. Selain istilah tersebut adapula istilah individu introvert dan extrovert. Introvert ialah sikap kecenderangan orang untuk menarik diri dari lingkungan sosialnya. Minat, sikap ataupun keputusan yang dibuat umumnya hanya berdasarkan pendapat, perasaan dan pemikirannya saja. Seseorang yang introvert biasanyapendiam dan tidak membutuhkan bantuan orang lain karena merasa ia dapat memenuhi kebutuhannya sendiri. Sedangkan sikap extrovert ialah sikap yang cenderung mengarah pada luar dirinya. Minat, sikap atau keputusan biasanya diambil bukan berdasarkan dari dirinya namun dari luar dirinya. Seseorang yang extrovert cenderung aktif, suka berteman dan ramah. Maka dari itu perkembangan sosial sangat pentng untuk dikembangkan supaya menjadi bekal dasar untuk anak menghadapi kehidupan sosianya utuk saat ini dan kelak. Hal tersebut dilatarbelakangi oleh masalah yang ditemukan setelah melakukan observasi pada kemampuan sosial anak di TK Sukahaji. Salah satu masalah yang ditemukan yaitu kurangnya kadar interaksi anak yang mempengaruhi pada kemampuan sosialisasi anak.

Loree (dalam Nugraha A. \& Rachmawati Y. 2007. hal 1.18) 'bahwa sosialisasi merupakan suatu proses dimana individu terutama anak untuk melatih kepekaan terhadap rangsangan sosial terhadap tekanan dan tuntutan kehidupan, dimana anak diharuskan untuk bisa bergaul dan bertingkah laku sesuai dengan orang yang berada dilingkungannya'. Dengan kata lain sosialisasi ialah suatu kemampuan untuk berhadapan dan bersikap dengan lingkungan sosial sesuai dengan tuntutan sosial yang ada. Saat bersosialisasi maka akan terjadi interaksi satu dengan yang lainnya. Pada saat 
bersosialisasi pasti akan terjadi interksi dengan orang lain Menurut Thibaut dan Kelly (dalam Asrori dan Muhamad A, 2006, him 87) mendefinisikan 'interaksi sebagai peristiwa saling mempengaruhi satu sama lain ketika dua orang atau lebih hadir bersama, mereka menciptakan suatu hasil satu sama lain, atau berkomunikasi satu sama lain.' Adapun pengertian interaksi sosial menurut Basrowi (2005, him 138) kurang lebih adalah 'hubungan dinamis yang mempertemukan orang dengan orang lainnya, kelompok dengan kelompok lainnya, maupun orang dengan kelompok manusia.' Bentuknya tidak hanya bersifat kerjasama, tetapi bisa juga berbentuk tindakan persaingan, pertikaian, dan sejenisnya.

Dengan demikian interaksi adalah suatu hubungan atau kegiatan yang dilakukan seseorang atau kelompok dengan orang atau kelompok lain yang dapat menghasilkan sesuatu baik tindakan atau sikap. Apabila perkembangan social anak dilakukan sesuai dengan tugas perkembangannya maka aspek perkembangan sosialnya akan berkembang dengan baik. Seiring dengan waktu yang berjalan anak akan bertumbuh dan berkembang menjadi orang yang dewasa, anak akan mulai mengenal kehidupan bermasyarakat dan hidup dilingkungan sosial.Menurut teori perkembangan sosial menurut Erickson (dalam Herawati, 2006) perkembangan sosial anak prasekolah berada pada tahapan Innitiative Vs Guilt pada tahap ini anak sudah mulai mengenal konsep dirinya sebagai individu, pada tahap ini anak memasuki lingkungan sosial yang lebih luas dan dituntut untuk mengembangkan perilaku yang sesuai dengan harapan lingkungan sosialnya. Anak dituntut untuk mengembangkan inisiatif dan tanggung jawab pada setiap kegiatannya. Apabila anak tidak memiliki rasa inisiatif dan tanggung jawab maka ia akan merasa bersalah dan takut untuk melakukan sesuatu karena ketakutan akan rasa bersalah. Pada tahap ini lingkungan sosial anak akan semakin luas dari sebelumnya yang sangat bergantung pada lingkungan sosial di keluarga, saat itu anak lebih berkeinginan memperluas pergaulannya. Hal inipun sejalan dengan pemikiran Dariyo, (2007) beliau berpendapat bahwa pada masa anak-anak awal (early chidhood) walaupun masih bergantung pada orang tua namun pada masa ini sudah ditandai dengan kemandirian, kemampuan mengontrol diri dan keinginan untuk memperluas pergaulan dengan anakanak sebaya lainnya. Pergaulan yang semakin luas akan mengurangi egosentris, kelekatan emosi dengan orang tua, mengurangi sifat irasional anak. Dalam pergaulan itu anak masing-masing akan saling mengkritik, memuji, bertengkar, berbeda pendapat, adaptasi norma- norma sosial yang bara bahkan terjadi konflik, namun dengan hal tersebut akan menimbulkan sikap kompromi.Cara yang dapat ditempuh untuk meningkatkan perkembangan sosial anak salah satunya adalah dengan menggunakan metode bermain secara kolaboratif, dimana metode ini dapat memberikan pengalaman belajar pada anak yang dilakukan secara berkelompok atau berkolaborasi dengan menghadapkan anak pada persoalan sehari-hari yang harus dipecahkan secara berkelompok sesuai dengan masing- masing kemampuan anak.Gordon (Moeslichatoen. 2004) "Bahwa dalam kehidupan kelompok, masing- masing anak belajar mengatur diri sendiri agar bisa membina persahabatan, berperan dalam kegiatan kelompok, memecahkan masalah yang dihadapi oleh kelompok, dan bekerja sama untuk mencapai tujuan bersama". Berdasarkan pendapat tersebut bahwa pengaturan diri dalam kehidupan anak dapat membina persahabatan, hal tersebut berperan dalam kegiatan kelompok baik dalam memecahkan masalah maupun kerjasama antarkelompok untuk mencapai sebuah tujuan. Sejalan dengan pendapat Abidin (2009 him 39) bahwa pada dasar bermain itu adalah berinteraksi. Saat anak bermain dan berinteraksi secara tidak sadar anak sedang belajar dan memperoleh berbagai keterampilan sosial. Saat bermain anak dapat belajar 
bekerja sama, bertukar pendapat, belajar untuk memahami persepsi orang lain, belajar menyesuaikan diri dengan harapan lingkungan, dan berkolaborasi. Bermain merupakan kegiatan yang menyenangkan bagi siapapun baik anak-anak ataupun orang dewasa.

Moeslihatoen (2004) menyatakan bahwa melalui bermain anak dapat mengembangkan kemampuan sosialnya, bermain secara kolaboratif bias digunakan untuk mengembangkan perkembangan sosial anak, anak dituntut untuk saling berinteraksi dengan yang lainnya baik teman terdekatnya atau bukan, hal tersebut menimbulkan adanya peningkatan perkembangan sosial anak. Menurut Isjoni (2011, him 88) "bermain merupakan kekuatan hidup. Kegiatan bermain sesuatu yang esensial bagi kehidupan." Kegiatan bermain merupakan dunia anak, kegiatan tersebut merupakan kegiatan yang mengasyikan bagi anak, dengan kegiatan bermain anak dapat mengekspresikan, mengeluarkan tenaga dan merasa senang, begitu pula seharusnya pembelajaran pada anak usia dini harus meliputi kegiatan yang menyenangkan. Menurut Jacob. C (Jacob, hal 4) Belajar kolaboratif adalah suatu filosofi personal, benar-benar bukan suatu teknik kelas. Dalam semua situasi di mana orang datang bersama-sama dalam kelompok, dorongan suatu cara menghadapi orang yang respek dan menyoroti kemampuan dan kontribusi anggota kelompok masing-masing. Ada suatu berbagi (sharing) otoritas dan penerimaan tanggung jawab di antara anggota kelompok untuk tindakan kelompok. Hal utama dari belajar kolabratif berdasarkan pada keberagaman kemampuan anak untuk bekerja sama oleh tiap anggota kelompok, dibedakan dengan kompetensi di mana anggota kelompok lain masing-masing terbaik.

Menurut Rose dan Edleson (dalam Kathryn G dan David Gerald, hal 6) dengan berkelompok anak bisa meningkatkan perubahan dimana mereka diajak untuk saling berinteraksi. Mereka juga bependapat bahwa "anak-anak mendapatkan banyak pelajaran dengan cara saling berinteraksi, saling mengamati, dan saling mendengar antarsesama teman-sebayanya." Bermain secara kolaboratif merupakan aktivitas yang dilakukan secara bersama-sama menurut Mild Parten (Tedjasaputra, 2001) "bermain dengan bersama- sama (Cooperative Play) merupakan tingkat tertinggi dalam tahapan perkembangan bermain yang mencerminkan tingkat perkembangan sosial anak dimana kegiatan bermain tersebut terlihat adanya peningkatan kadar interaksi sosial, mulai dari bermain sendiri sampai bermain bersama." Sehubungan bahwa bermainberkelompok merupakan aktivitas yangmembutuhkan kerjasama antar anggota maka disana pasti akan terjadi interaksi sosial. Secara sadar ataupun tidak anak akan belajar untuk berkomunikasi, mengomunikasikan ide atau pendapatnya didalam kelompok. Pada metode ini anak secara berkelompok memecahkan masalah dan saling berinteraksi satu dengan yang lainnya. Sangat penting seorang anak terlibat dengan orang lain selain dirinya sendiri. Pada kegiatan bermain secara kolaboatif guru berperan sebagai pendamping dan fasilitator. Proses kegiatan bermain secara kolaboratif ini terbagi menjadi 3 tahap yaitu dengan perencanaan kegiatan, pelaksanaan kegiatan dan evaluasi pada kegiatan. Guru haras benar-benar mengetahui keberagaman kemampuan anak untuk mengkolaborasikan anak dalam kelompok.

\section{B. METODE}

Penelitian tersebut menggunakan model Penelitian Tindakan Kelas. Menurut Kusnadar (2012) penelitian tindakan dapat diartikan sebagai kegiatan mencari objek dengan menggunakan metodologi tertentu, untuk mendapatkan data yang bermanfaat, selanjutnya dianalisis untuk mendapatkan kesimpulan. Menurut Sumadayo (2013) menyatakan bahwa penelitian tindakan merupakan bentuk penelitian sosial yang 
melibatkan praktek yang diteliti dalam proses penelitian dengan tahap-tahap yang terdiri: (1) perencanaan tindakan; (2) pelaksanaan tindakan; (3) pengamatan pelaksanaan dan (4) pelaksanaan refleksi tindakan. Dalam penelitian tindakan diharapkan semua objek terkena dampak oleh praktek itu dan terlibat dalam proses penelitian. Penelitian tersebut menggunakan model Elliot yang terdiri 3 siklus, 9 tindakan.

Setelah data terkumpul selanjutnya diolah dengan menggunakan teknik kuantitaif, teknik kualitatif dan triangulasi, sehingga mendapatkan hasil yang lengkap dan valid. Teknik Kuantitatif Teknik kuantitatif merupakan teknik analisis data yang menekankan teori rata-rata kelas untuk mengetahui peningkatan peserta didik. Teknik tersebut didapat dari performa, setelah peneliti memberikan tindakan. Teknik Kualitatif

Teknik kualitatif merupakan teknik analisis data yang berapa kalimat untuk menjelaskan tentang perkembangan peserta didik, setelah diberikan tindakan. Teknik tersebut didapat setelah peneliti menelaah hasil dari wawancara, dokumentasi, dan tes, kemudian dideskripsikan dan disimpulkan. Triangulasi, merupakan teknik penggabungan untuk meyakinkan tentang keabsahaan tentang peneliti. Data triangulasi didapat dari data wawancara, dokumentasi dan tes. Penelitian dilakukan pada TK Suka Haji dengan jumlah siswa 13 yang terdiri dari laki-laki 5 dan 8 perempuan berjumlah 10 siswa yang berusia 5-6 tahun dengan jumlah 1 guru utama. TK Suka Haji berada di jalan Pesantren no IA Rt 02 Rw 17 Desa Cimekar Kecamatan Cileunyi Kabupaten Bandung.

Instrumen yang digunakan pada penelitian tersebut yakni skoring rubbrik. Instrumen tersebut cocok untuk digunakan, karena data nilai yang di dapat akan valid berdasarkan kemampuandankebutuhan peserta didik.

Berikut beberapa indikator yang akan digunakan saat penelitian:

1. Anak dapat berpartisipasi dalam kegiatan bermain

2. Anak mengendalikan dirinya dalam kegiatan bermain

3. Anak dapat bersikap kooperatif

Dengan teman saat bermain Masalah dan penyebab tersebut dapat dipecahkan melalui metode bermain secara kolaoratif. Pada dasarnya pembelajaran kolaboratif merujuk pada suatu metode pembelajaran dimana siswa pada tingkat performa yang berbeda bekerja bersama dalam suatu kelompok kecil. Penerapan kegiatan bermain secara kolaboratif dapat memberikan kesempatan kepada anak untuk berinteraksi dengan temannya, anak dapat menjalin hubungan, berkomunikasi, dan berhadapan dengan lingkungan nyata. Pengertian pembelajaran kolaboratif menekankan pentingnya interaksi sosial antar individu dalam kelompok untuk membangun pemahaman atau pengetahuan setiap anggota kelompok.

\section{PEMBAHASAN}

\section{Siklus 1}

Siklus I dilaksanakan melalui tiga tindakan. Tema yang digunakan adalah permainan tradisional, pada tindakan 1 kegiatan bermain secara kolaboratif menggunakan permainan memasukan pensil ke botol, pada tindakan 2 anak bermain pindah sarung, dan pada tindakan 3 anak bermain permainan 
galah asin. Pada siklus ini peneliti menggunakan media pensil, botol, tali, dan sarung.

Pada siklus I, penerapan metode bermain secara kolaboratif belum menunjukan hasil meningkat yang sigifikan, pada indikator 1 menghasilkan rerata 1,83, pada indikator 2 menghasilan rerata 1,67 dan pada indikator 3 menghasilan rerata 1,83

\section{Perkembangan Sosial Anak Siklus 1}

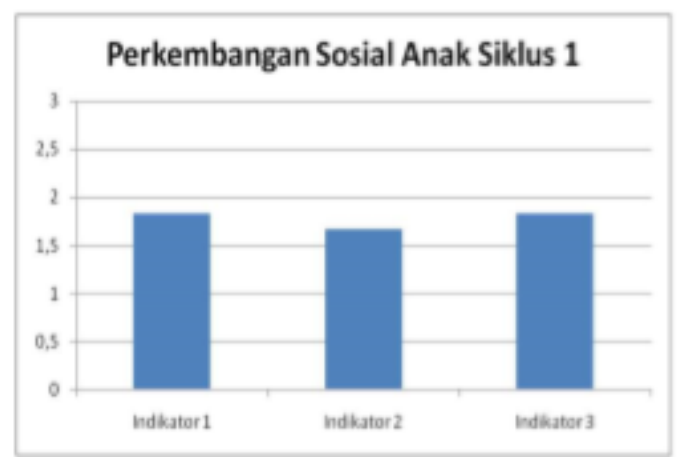

Berdasarkan tabel tersebut dapat dilihat bahwa hasil siklus I belum mencapai kategori indikator yang ingin dicapai. Hal ini dikarenakan beberapa hal, media yang digunakan kurang menarik sehingga anak merasa tidak tertarik dengan kegiatan dan peneliti kurang jelas menjelaskan atturan main sehingga anak menjadi sedikit bingung dan kurang antusias. Maka dari itu, peneliti harus merancang ulang kegiatan bermain secara kolaboratif dengan memperbaiki dan melengkapi kekurangan sehingga pelaksanaan siklus yang kedua dapat lebih baik lagi.

\section{Siklus 2}

Peneliti melaksanakan permainan secara kolaboratif dengan tema geometri dan gejala alam (siang dan malam) dengan kegiatan bermain salur bola, pindah bola, dan permainan dengar aku. Pada siklus ini peneliti menggunakan media bola, karton, wadah, sendok dan penutup mata.

Pada siklus 2, penerapan metode bermain secara kolaboratif menunjukan hasil yang meningkat dari siklus sebelumnya. Hasi rerata pada indikator 1 yaitu 2,11, rerata pada indikator 2 yaitu 2,07, dan rerata pada indikator 3 yaitu 2,07

\section{Perkembangan Sosial Anak Siklus 2}

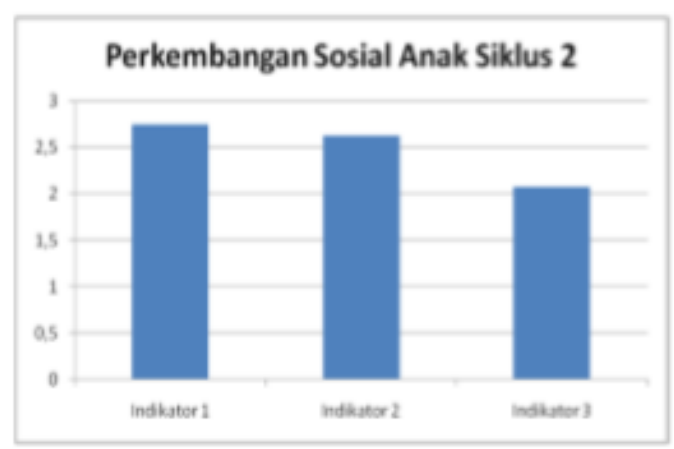


Berdasarkan tabel di atas, rata-rata perkembangan sosial anak meningkat daripada siklus sebelumnya. Anak sudah menunjukan antusiias mengikuti kegiatan berkelompok, mau berpartisipasi dan bekerja sama dalam kelompok. Peneliti haras teras mengembangkan peningkatan tersebut dengan menyiapkan media, jenis kegiatan permainan yang lebih menarik lagi bagi anak supaya pada siklus 3 lebih baik lagi.

\section{Siklus 3}

Pada siklus 3 peneliti menggunakan tema lingkunganku dengan bermain membuat poster lingkungan yang sehat, bermain puzzle dan bermain permainan tradisional bakiak. Peniiti menggunakan media gambar dan bakiak buatan dari kardus.

Pada siklus 3 perkembangan sosial anak meningkat sesuai dengan harapan. Anak-anak mau untuk berpartisipasi aktif dalam kegiatan kelompok, mengendalikan dirinya saat bermain dan bekerja sama dalam kelompok. Pada siklus 3 ini hasil rata-rata tiap indikator sudah melampaui standar peneliti untuk mengembangkan perkembangan sosial anak. Pada indikator 1 menghasilkan rerata 2,75 pada indikator 2 menghasilkan rerata 2,62 pada indikator 3 menghasilkan rerata 2,69

\section{Perkembangan Sosial Anak Siklus 3}

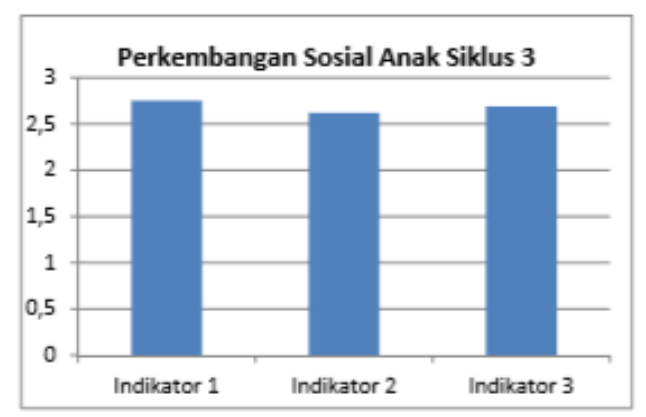

Berdasarkan hasil penelitian yang telah dilakukan yaitu penerapan metode bermain secara kolaboratif ternyata mampu meningkatkan perkembangan sosial anak. dalam proses pengembangannya, anak sudah mampu memunculkan aktivitas-aktivitas yang diharapkan guru. Peningkatan perkembangan sosial anak diantaranya, anak sudah bisa bersosialisasi dengan baik dengan teman-temannya, mau mengikuti kegiatan bermain secara berkelompok, anak aktif berpartisipasi dengan kelompok saat bermain, anak berkomunikasi aktif dalam bermain, anak sudah bisa mengendalikan dirinya saat kegiatan bermain, anak dapat bekerja sama dalam kelompok saat bermain secara berkelompok, dll.Melalui kegiatan bermain pada anak, anak mampu mengikuti kegiatan pembelajaran dengan baik serta anak menjadi terbiasa dengan pembelajaran secara kelompok. Oleh karena itu dalam upaya meningkatkan perkembangan sosial anak dapat menggunakan metode bermain berbasis kolaboratif dalam kegiatan pengembangan yang didukung dengan lingkungan pembelajaran yang memadai serta keterampilan guru dalam menciptakan permainan yang menantang rasa ingin tahu anak.

\section{PENUTUP}

Dengan menerapkan metode bermain secara kolaboratif pada anak dapat meningkatkan perkembangan sosial anak. Hal tersebut terjadi pada setiap siklusnya. Adapun nilai rata-rata perkembangan anak pada siklus 1 yaitu 1,78 meningkat pada siklus 2 rata-rata kelas menjadi 2,09 dan rata-rata kelas siklus 3 mengalami peningkatan 
menjadi 2,69.

\section{DAFTAR PUSTAKA}

Abidin, Y. (2009). Bermain. Bandung: Rizqi Press.

Asrori, M dan Mohammad A. (2006). Psikologi Remaja Perkembangan Peserta Didik. Jakarta: PT Bumi Aksara.

Basrowi. (2005). Pengantar Sosiologi. Bogor: Ghalia Indonesia.

Dariyo, A. (2007). Psikologi Perkembangan Anak Usia Tiga Tahun Pertama. Bandung: PT Refika Aditama

Departemen Pendidikan dan Kebudayaan. (2014). Peraturan pemerintah no 137 standar nasional pendidikan anak usia dini. Jakarta: Depdikbud

Departemen Pendidikan dan Kebudayaan. (2014). Peraturan pemerintah no 146 kurikulum 2013 pendidikan anak usia dini. Jakarta: Depdikbud

Herawati, I. (2006). PsikologiPerkembangan 111. Bandung: Universitas Pendidikan Indonesia

Isjoni. (2011). Cooperative Learning. Bandung: Alfabetha

Jacob, C. Belajar Kolaboratif Lawan Kooperatif. Bandung: FPMIPA UPI

Kathryn dan David. (2013) Menangani Anak Dalam Kelompok. Yogyakarta: Pustaka Belajar

Kusnandar. (2012). Langkah Mudah Penelitian Tindakan Kelas Sebagai Pengembangan Profesi Guru. Jakarta: PT Raja GrafindoPustaka

Moeslichatoen, (2004). Metode Pengajaran Di Taman Kanak- kanak. Jakarta: Rineka Ciptadan Depdikbud.

Nugraha, A dan rachmawati, Y. (2007). Metode Pengembangan Sosial Emosional. Bandung: Universitas Terbuka.

Sumadayo, Syamsu. (2013). Penelitian Tindakan Kelas. Yogyakarta. Graha Ilmu

Tedjasaputra, M.Y. (2001). Bermain, Mainan, dan Permainan untuk Pendidikan Usia Dini. Jakarta: PT. Grasindo

Yusuf, S. (2006). Psikologi Perkembangan Anak dan Remaja. Bandung: PT Remaja Rosdakarya 